\title{
Overtourism in Jeju Island: The Influencing Factors and Mediating Role of Quality of Life
}

\author{
Mincheol KIM ${ }^{1}$, Kwang-Woong $\mathrm{CHOI}^{2}$, Mona CHANG ${ }^{3}$, Chang-Hun $\mathrm{LEE}^{4}$
}

Received: November 29, 2019 Revised: March 15, 2020 Accepted: March 31, 2020

\begin{abstract}
The purpose of this study is to analyze how the problems caused by overtourism affect the quality of life of Jeju residents and their perceptions of the overtourism phenomenon by exploring related factors for future policy implications. In the research model, each independent factor related to tourists affects the quality of life of residents, and the mediation variable (QoL) ultimately agrees with overtourism. This study uses Partial Least Squares-Structural Equation Modeling (PLS-SEM), which is less influenced by the sample size. The research is based on 360 questionnaires. The test results showed that cultural factors affected the QoL statistically at $1 \%$ significance level, and economic factors were significant at 5\%. The quality of life variable affects the agreement of overtourism (p-value $1 \%$ significance level). An indirect effect analysis on whether each independent factor affects the overtourism factor through the parameter of the QoL of the residents showed that the cultural factor at 5\% level statistically affected it, and economic factors were significant at $10 \%$. In conclusion, we recommend implementing both economic and cultural factors to reduce the negative perception of overtourism for the policy planning. Further research in multiple aspects should be continued to overcome the vulnerability of the Island destination tourism.
\end{abstract}

Keywords : Quality of Life, Overtourism, Tourism Capacity, PLS-SEM, Jeju Island

JEL Classification Code: C45, C53, Q53, Z32

\section{Introduction}

Tourism is widely known to provide advantages to tourists like relaxation, recreation, adventure and cultural experiences while generating income and employment at the destination places (Hall \& Rath, 2007; Mustafa, 2019; Pham, Andereck, \& Vogt, 2019). Among the effects of tourism, many studies have been conducted on the economic benefits

${ }^{1}$ First Author. Professor, Dept. of Management Information System, Tourism, Business, and Economic Research Institute, Jeju National University, Jeju, Korea. Email: mck1292@jejunu.ac.kr ${ }^{2} \mathrm{PhD}$ Candidate, Dept. of Tourism Management, Jeju National

University, Jeju, Korea. Email: kwchoi1983@jejunu.ac.kr

${ }^{3}$ Corresponding Author, $\mathrm{PhD}$ Candidate, Dept. of Tourism

Development, Jeju National University, Jeju, Korea.

Email: cmn6861@jejunu.ac.kr

${ }^{4}$ Lecturer, Management Science and Entrepreneurship, University of

Essex, United Kingdom, Email: c.lee@essex.ac.uk

(c) Copyright: The Author(s)

This is an Open Access article distributed under the terms of the Creative Commons Attribution Non-Commercial License (http://Creativecommons.org/licenses/by-nc/4.0/) which permits unrestricted noncommercial use, distribution, and reproduction in any medium, provided the original work is properly cited. and disadvantages of tourism (Archer, Cooper, \& Ruhanen, 2005; Diedrich \& García-Buades, 2009; Vogel, 2016), which is considered the most important. The number of tourists is steadily increasing due to rising global income and the reduction of travel expenses, thanks to the widespread low-cost airlines and affordable services. Many countries regard tourism as a critical multi-faceted industry (Lawton, 2017). In addition, the expansion of accommodationsharing businesses, like Airbnb, as well technical support in mobile services such as language translation, travel guides and maps, make traveling inexpensive and convenient, thus, being factors in tourism demand (Guttentag, 2015; Capocchi, Vallone, Pierotti, \& Amaduzzi, 2019; Oklevik, Gössling, Hall, Steen Jacobsen, Grøtte, \& McCabe, 2019). It is an undeniable facts that tourism brings wellbeing to both tourists and residents of destinations in many ways, but it has unexpected or sometimes predictable problems when it is 'too much' as we are seeing them emerging around famous urban tourist destinations around the world. Overtourism is a concept that encompasses a variety of complications caused by tourists' visits that exceed the capacity of tourist destinations. As the issue of overtourism emerges, along with the right of tourists to enjoy this activity, the sustainability of 
tourist destinations and the rights of local residents are also considered (Perkumienė \& Pranskūnienė, 2019).

The phenomenon of overtourism is a threat to the quality of life of residents in tourist destinations, and overtourism is occurring in Asia, Oceania, and South America, and especially in Europe's popular attractions (Erschbamer \& Pechlaner, 2018; Avond, Bacari, Limea, Seraphin, Gowreesunkar, \& Mhanna, 2019). As the emphasis on quality is spreading in some tourist destinations where overtourism is severe, antitourist sentiments have expanded, and direct protests against the tourists have been witnessed, leading to the "Tourismphobia" concept (Perkumienė \& Pranskūnienè, 2019).

Issues caused by overtourism include sociocultural problems such as deterioration of the quality of life of local residents and destruction of cultural heritage sites, environmental issues threatened by sustainability of natural ecosystems, and limited economic benefits to local residents. Jeju, Korea's representative island tourist destination, is gradually showing those obstacle associated overtourism (Choi, Kim, Chang, \& Koo, 2019). Island tourism destinations have a spatial limitation that is closely related to the concept of carrying capacity due to the uniqueness of islands, and the ecological environment may be easily damaged (Hall, 2012; Azzopardi, 2011). Thus, anticipative approaches and systematic studies on overtourism are very necessary.

In particular, Jeju Province, Korea's largest island, has only 700,000 residents, with annual visitors exceeding 10 million for the first time in 2013. Since 2015, 150 million people visited the island -20 times more than the resident population (Chang, Heo, \& Lim, 2019). Moreover, Jeju is considered an anthropologically-sensitive area in that the majority of tourists are domestic visitors compared to other competitive tourist destinations in Asia such as Bangkok, Kuala Lumpur, Singapore and Jakarta.

In addition to the surge of tourists, the attraction of tourist destination has also influenced the attractiveness for Koreans from the mainland, which has led to a rapid increase in the number of immigrants in recent year (Chang et al., 2019). As a result, various social problems have been subtly entangled with issues such as the influx of tourists and the increase in the population of the region. Therefore, it is urgent to consider whether it is a temporary social phenomenon or the effect of tourism, and to find a solution in order to prepare the next steps to improve social infrastructure.

In other words, it would be very practical to investigate, analyze, and diagnose the opinions of residents before this series of issues affect their quality of life, such as fluctuations in real-estate prices, instability of living expenses, traffic congestions and waste management matters. Thus, the main purpose of this study is to elicit policy implications that are closely related, not only to Jeju tourism, but also to residents' lives.

\section{Theoretical Background}

\subsection{Overtourism and Carrying Capacity}

Despite the global economic downturn, by the third quarter of 2019, the number of international tourists increased by $4 \%$ compared to the previous year (UNWTO, 2019), and as of 2018, the world's tourist population is $\$ 1.4$ billion with an impact on the economy of about $\$ 1.7$ trillion, making up $2 \%$ of global GDP (Blackall, 2019). Since tourism is part of human life or activity, it causes a variety of effects or impacts that cannot be interpreted in only one aspect of the economy or society. As the number of tourists grows and the total spending increases, the impacts of tourism are often expressed as side effects. Butler (1980) has pointed out in his tourist area life cycle theory that there are already regional movements such as restrictions on tourists in a few European countries like the United Kingdom, Spain and France, in order to secure the conservation of finite tourism resources and prevent the destruction of the environment. While Butler's Tourism Destination Life Cycle Model focuses on the development stage of tourist attractions, Doxey's Irridex Model (1975), a theory that explains the impact of tourism, became a model that classifies the change of emotion of local residents according to the stage of the development of tourist attractions. These two models show the negative change in the phases of the impact of over-development at the tourist destinations, presenting a theoretical basis for the multi-aspect conflict between the residents' interests and destination development, owing to an industrial development especially aviation sectors (Faulkner \& Tideswell, 1997; Zhang, Inbakaran, \& Jackson, 2006; Shafaei \& Mohamed, 2015; Martín, Guaita Martínez, \& Salinas Fernández, 2018; Gutiérrez-Taño, Garau-Vadell, \& Díaz-Armas, 2019; Kuščer \& Mihalič, 2019; Oklevik et al., 2019; Pham at al., 2019).

In this regard, phenomena caused by excessive tourist visits compared to the number of local residents are called overtourism, which is often accepted as the same term like tourist's carrying capacity. The concept of carrying capacity, originally derived from defining the maximum populations of specific regions in agriculture, ecosystems, and biology, has been widely used in tourism since the 1960s, and it has been mentioned in relation to the growing debate on sustainability, most concerned with overtourism (Faulkner \& Tideswell, 1997; Ballester, 2018; Coccossis \& Mexa, 2017; UNWTO, 2018; Benner, 2019; Capocchi et al., 2019). UNWTO defines the carrying capacity of the tourist destination as "the maximum number of people that may visit a tourist destination at the same time, without causing destruction of the physical, economic and socio-cultural environment and an unacceptable decrease in the quality of visitors' satisfaction" (Koens, Postma, \& Papp, 2018; Joshi 
\& Dahal, 2019). It is also frequently used as an approach to the negative effects of tourism (Butler, 1999; Saarinen, 2006; Muler Gonzalez, Coromina, \& Gali, 2018; Capocchi et al., 2019).

However, it is almost impossible to quantitatively measure the acceptability of different tourist destinations (regions) with ecological, social, cognitive, safety and spatial constraints (Brougham \& Butler, 1981; Ratz, 2003; Capocchi et al., 2019; Szromek, Kruczek, \& Walas, 2020). Invigorating the local economy with an adequate number of tourists somewhat contributes the residents' lives. Nevertheless, once the excessive number of tourists reaches up to certain level, residents may experience discomfort and inconvenience with negative perceptions. The other terms that define negative phenomena such as touristification, tourismphobia, and antitourism are in line with overtourism.

\subsection{Overtourism and Jeju Island}

Overtourism is considered a worldwide phenomenon, especially in tourist attractions of West Europe, often causing anti-tourism movements that affect regional economies (Seraphin, Sheeran, \& Pilato, 2018). Representative overtourism areas known as urban tourism destinations like Venice (Italy) and Barcelona (Spain), cities where the quality of life of local residents deteriorates due to crowds of tourists along with serious conflicts or protests between tourists and locals (Avond et al., 2019; Jordan, Lesar, \& Spencer, 2019). As a countermeasure to overtourism, the Barcelona administration has banned the construction of new hotels and monitors noise and pollution using SmartCitizen Kits concerning the quality of life for local residents. Venice authorities banned new accommodations' business in historic centers and new cruise ships, giving privilege access to locals (Goodwin, 2019). The policy response to problems of tourism has begun, however, it is still challenging to solve the fundamental matters.

Overtourism is gradually taking place outside of Europe, for example, in Maya Bay, Thailand, where tourists are restricted from entering the tourist area in the name of protecting the ecosystem, fearing that the places would lose value due to excessive turmoil and environmental pollution (Avond et al., 2019). To overcome the economic impact of the SARS epidemic that swept Hong Kong in 2003, the Chinese government has opened a range of special Hong Kong access permits to 49 urban residents across China since 2007, which was previously requiring permits for only three Guangdong provinces. Subsequently, traders and tourists from mainland China, who have been moving to Hong Kong since then, have resulted in increased irritation between visitors and residents (Cheung \& Li, 2019). The characteristics of island tourism destinations may be more controversial than the urban destinations due to their vulnerability. As island tourist destinations, Maltese islands and Iceland have been pointed out. Being concerned as overtourism islands, they have been pointed out for both the protection of the ecological environment and the quality of life of local residents, that became an important issue in Maltese islands and Iceland (Avond et al., 2019; Azzopardi., 2011).

The range of issues in the study of the effects of overtourism on Jeju Island can be widely discussed in multidimension perspective including the preservation of cultural and historical resources, noise, garbage, traffic congestion, real estate, privacy, and local image (Martín et al., 2018), congestion, inconvenience, inflation, invasion, touristic damage (Faulkner \& Tideswell, 1997), local living expenses, locality, cultural and environmental damage, and tourist hatred (Koens et al., 2018; Benner, 2019). Recent issues on Jeju Island can easily be drawn from the commonalities of the overtourism effects, as most researchers are concerned that the negative impacts of overtourism can lead to a more serious social phenomenon of the tourist destinations (Koens et al., 2018; Benner, 2019).

In Korea, with a relatively short history of research on overtourism, more careful observation and diagnosis are necessary, considering that the influence of Internet and mass media might be more sensitive in terms of perception. Jeju Island was listed as the only triple-crown winner, designated as a Biosphere Reserve in 2002, World Natural Heritage Site in 2007, and Global Geopark in 2010. Since then, it has earned a global reputation (Kim, Thapa, \& Kim, 2018). The number of annual visitors on Jeju Island rapidly increased to 10 million around 2010 , reaching 15 million since 2016. Notably, the number of domestic tourists has shown an increase in the number of days of staying along with the prevalence of new tourism pattern of long-term stays called 'Living in Jeju for a Month' (Chang et al., 2019). On December 26, the Jeju Provincial Office announced that the total number of tourists for a year until December 25, 2019, increased by $6.6 \%$ year-on-year to 15.2 million, including 1.7 million foreigners (Jeju Weekly, 2020). Jeju Island has a different geographical and socio-demographic background from the other tourist destinations that are experiencing the above-mentioned overtourism. One of major recent issues is about waste management on the island due to its limited landfill. (Chang, Xing, Zhang, Han, \& Kim, 2020). Thus, a different approach to overtourism may be needed. This will be the first study on the factors of concern over the phenomenon of tourism Jeju residents' consciousness.

\subsection{Derivation of Overtourism Factors}

This study classified factors of overtourism into economic, social, cultural, and environmental factors, and derived them 
by reviewing related prior studies in order to grasp the effects of factors on the quality of life and overtourism perception of local residents (Liu, Sheldon, \& Var, 1987; Martín et al., 2018; Muler Gonzalez et al., 2018; Choi et al., 2019; Jordan et al., 2019; Kuščer \& Mihalič, 2019). The selected factors are shown in Table 1.

We examined previous studies that analyzed factors affecting the quality of life through the phenomenon of overtourism and the perception or stress of local residents. A wide range of common factors is discussed, while securing diversity in Europe, Americas, and Asia. In addition, with regard to the phenomenon of overtourism, those factors were common issues to both urban and island tourist destinations.

First, 169 factors were derived from six papers related to overtourism from previous studies, and they were reduced to 38 in the process of classifying them into economic, social, cultural and environmental factors. These 38 factors that were then reduced to 20; five questions in each category were selected as issues or concerns on Jeju Island related to overtourism. While checking the satisfaction level, the perceptions of local residents about the quality of life were gathered, and whether or not they recognize the status of Jeju tourism as an overtourism.

The issues associated with overtourism are largely negative, but the economic benefits from the increase in tourists (Andereck, Valentine, Knopf, \& Vogt, 2005; Kim, Uysal, \& Sirgy, 2013), the opportunities for various cultural activities in the community, and the increasing number of restaurants and cafés affect the positive perception among those factors (Martín et al., 2018; Jordan et al., 2019; Kuščer $\&$ Mihalič, 2019).

A total of 22 items were finalized (Table 1). They formed the questions asked to the local residents, so that most of the questionnaires begin with 'Do you think the excessive number of tourists on Jeju Island cause ...'.

Table 1: Variables and Questionnaires under Overtourism by Category

\begin{tabular}{|c|c|c|}
\hline Variable & Questionnaires & Sources \\
\hline \multirow{5}{*}{ Economic } & Preference of shopping in crowded places & \multirow{2}{*}{ Liu et al. (1987), Martín et al. (2018) } \\
\hline & Economic opportunities & \\
\hline & Regional economic development of Jeju & $\begin{array}{l}\text { Kuščer \& Mihalič (2019), Martín et al. (2018), Jordan et } \\
\text { al. (2019) }\end{array}$ \\
\hline & Damage of property market & \multirow{4}{*}{ Martín et al. (2018), Choi et al. (2019) } \\
\hline & Increase of living expenses & \\
\hline \multirow{5}{*}{ Social } & Safety issue & \\
\hline & Invasion of privacy & \\
\hline & Kindness drop toward tourists & Liu et al. (1987), Choi et al. (2019) \\
\hline & Congestion & Martín et al. (2018), Choi et al. (2019) \\
\hline & Tourists' concern for local residents & \multirow{2}{*}{$\begin{array}{l}\text { Liu et al. (1987), Muler Gonzalez et al. (2018), Jordan } \\
\text { et al. (2019) }\end{array}$} \\
\hline \multirow{5}{*}{ Cultural } & Various cultural activity opportunities & \\
\hline & Increase of good restaurants & \multirow{2}{*}{ Jordan et al., 2019, Kuščer \& Mihalič (2019) } \\
\hline & Increase of nice cafes & \\
\hline & Damage of historic sites & Martín et al. (2018), Choi et al. (2019) \\
\hline & Destruction of regional legitimacy & Liu et al. (1987), Choi et al. (2019) \\
\hline \multirow{5}{*}{ Environmental } & Air pollution & Martín et al. (2018), Kuščer \& Mihalič (2019) \\
\hline & Traffic congestion & \multirow{3}{*}{$\begin{array}{l}\text { Martín et al. (2018), Choi et al. (2019), Jordan et al. } \\
\text { (2019) }\end{array}$} \\
\hline & Waste management & \\
\hline & Noise \& odor & \\
\hline & Ecological environment & Liu et al. (1987), Choi et al. (2019) \\
\hline Quality of Life & Concern QoL of Residents & $\begin{array}{l}\text { Martín et al. (2018), Muler Gonzalez et al. (2018), } \\
\text { Jordan et al. (2019), Kuščer \& Mihalič (2019) }\end{array}$ \\
\hline Overtourism & Overtourism recognition & Choi et al. (2019) \\
\hline
\end{tabular}




\subsection{Quality of Life of Local Residents}

Quality of Life (QoL) is understandably a very subjective term about which hundreds of people may have different answers (Uysal, Sirgy, Woo, \& Kim, 2016). For Andereck and Nyaupane (2011) QoL "refers to one's satisfaction with life and feelings of contentment or fulfillment with one's experience in the world." In the tourism context, stakeholders of the specific tourist destination concern the general wellbeing of their residents, in economic, social, environmental and cultural perspectives of the major part of their lives. It is because the tourism impacts may bring them quantitative consequence both positive and negative effects depending on how the community treat the tourism business (Kim et al., 2013). The overtourism phenomenon is becoming more common among tourist destinations around the world, and the interests and rights of local stakeholders, especially those living in the region, have been drawing attention (Perkumiene \& Pranskūnienè, 2019).

As the tourism industry continues to grow, the number of visitors continues to increase, and the quality of life of local residents is undermined, leading to activities against tourists that hinder the growth of tourism (Koens et al., 2018). In those tourist destinations, local residents are moving toward defending the rights to enjoy their peaceful daily lives, that is, to ensure their quality of life (Goodwin, 2019).

In recent years, research on such movements has been actively conducted in academia. Among the negative effects of tourism, the certain environmental impact can be measured physically, but the negative impact on society is generally far more difficult to determine (Koens et al., 2018). This requires a more cautious and comprehensive approach, not only because the local people think negatively about the phenomenon of overtourism, but also because they cannot tolerate it (Koens et al., 2018). As a move to ensure the lives of local residents, there is a claim to improve the branding of tourist destinations, and that the re-branding of ever popular tourist destinations may cause additional overtourism (Seraphin, Sheeran, \& Pilato, 2018), so it is necessary to approach them strategically (Kim, 2018).

In addition, it has been argued that the introduction of Responsible Tourism should resolve the issue of overcrowding by tourists compared to local residents, and promotion of sustainable development for the coexistence of tourists and local residents (Goodwin, 2017). As such, there is a demand for an alternative to overtourism that guarantees the rights of local stakeholders centered on local residents, that is, the quality of life of local residents, while not detracting from tourist satisfaction. Therefore, community leaders who consider the residents' quality of life may get their support when implementing new tourism development plans (Pham et al., 2019). Meanwhile, municipal governments in the tourist destinations may consider Green Human Resource Management, a managerial aspect for local employees in the service industry as Tulsi and Ji (2019) suggest. Likewise, Jung (2020) has tried to understand employee's well-being as personal happiness in the service industry and found that the social networking affects most directly their concerns.

\section{Research Model and Hypotheses}

This research model includes economic, social, cultural and environmental factors from previous studies. Here, we considered the demographic characteristics (gender, age, education background, monthly income and residential areas) as control variables. They are shown on Table 2.

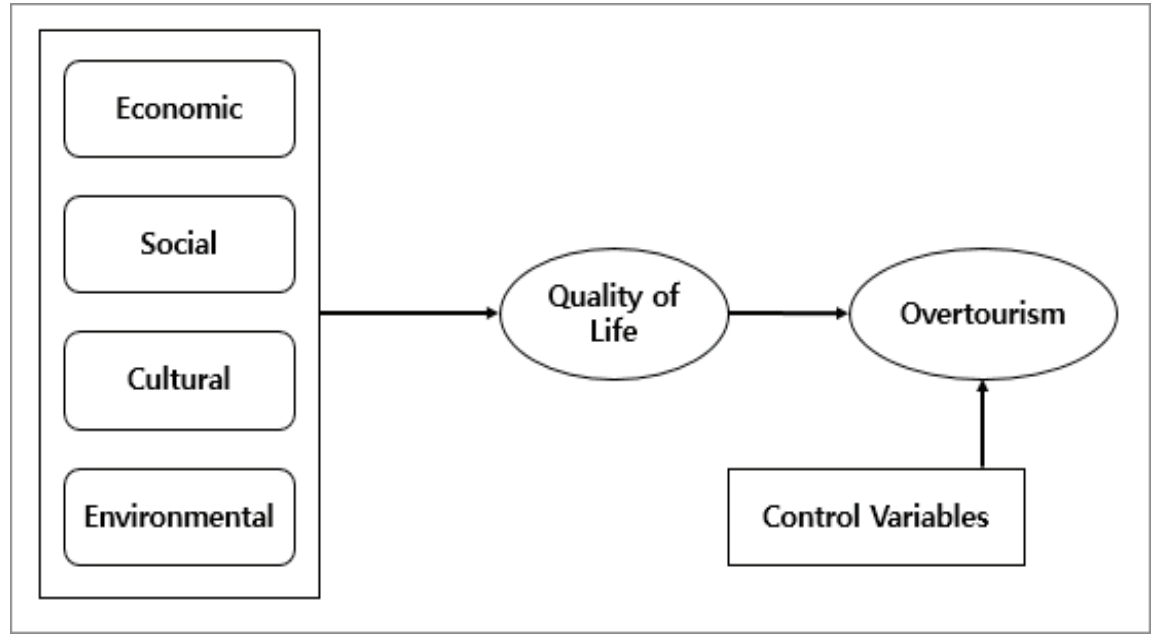

Figure 1: Research model 
In the research model, each independent factor (economic, social, cultural, and environmental) related to tourism affects the quality of life of residents, and the mediation variable (QoL) ultimately agrees with overtourism. Based on this logic, we posit the following hypotheses $(\mathrm{H} 1 \sim \mathrm{H} 3)$.

Hypothesis H1: Tourist-related factors affect the Quality of Life of residents.

Hypothesis H1-1: Tourist-related economic factors affect the Quality of Life of residents.

Hypothesis H1-2: Tourist-related social factors affect the Quality of Life of residents.

Hypothesis H1-3: Tourist-related cultural factors affect the Quality of Life of residents.

Hypothesis H1-4: Tourist-related environmental factors affect the Quality of Life of residents.

Hypothesis H2: Residents' Quality of Life affects whether they agree with overtourism.

Hypothesis H3: Demographic factors (gender, age, education, income, and residential areas) influence the agreement of overtourism.

Therefore, in this study, we use Partial Least SquaresStructural Equation Modeling (PLS-SEM), which focuses on the verification of paths and is less influenced by the sample size (Ringle, Sarstedt, \& Straub, 2012).

\section{Empirical Results}

\subsection{General Characteristics of Samples}

This study was conducted in Jeju Province of Korea with local residents, from November to December 2019. The purpose of the study was to collect data from the residents in order to understand their perception. The number of samples was assigned by age based on the composition of the population of Jeju Island, and the structured questionnaire was given accordingly. The minimum number of samples based on the number of questions was 157, and the researchers collected 370 samples out of 400 copies. Then 360 samples, except for 10 unfaithful answers, were coded for analysis. Looking at the characteristics of the respondents, females were participating more than males with $63.89 \%$, and 20 's $(26.11 \%)$ and 40 's $(26.11 \%)$ were the age of most respondents. In addition, the majority of respondents had high education backgrounds either university $(39.7 \%)$ or graduate school (30.83\%). Considering the possibility of influence of various parameters, data were separated by residential areas, into the downtown and the suburbs. Although the majority of respondents appeared to be city dwellers, the reason for this distinction was to explore the possibility that over-tourism may provoke different perceptions between people living in the city and those living in the suburbs.

Table 2: Sample Demographic Characteristics

\begin{tabular}{|c|c|c|c|}
\hline \multicolumn{2}{|r|}{ Categories } & $\mathbf{N}$ & $\%$ \\
\hline \multirow{2}{*}{ Gender } & Male & 130 & 36.11 \\
\hline & Female & 230 & 63.89 \\
\hline \multirow{6}{*}{ Age } & 19 and below & 12 & 3.33 \\
\hline & $20-29$ & 94 & 26.11 \\
\hline & $30-39$ & 79 & 21.94 \\
\hline & $40-49$ & 97 & 26.94 \\
\hline & $50-59$ & 65 & 18.06 \\
\hline & 60 and over & 13 & 3.61 \\
\hline \multirow{4}{*}{$\begin{array}{l}\text { Education } \\
\text { Background }\end{array}$} & Graduated from high school & 80 & 22.22 \\
\hline & Graduated from College and in College & 26 & 7.22 \\
\hline & Graduated from University and in University & 143 & 39.72 \\
\hline & Graduated from Graduate school and in Graduate school & 111 & 30.83 \\
\hline \multirow{5}{*}{$\begin{array}{l}\text { Monthly } \\
\text { Income }\end{array}$} & Less than 2 million won & 101 & 28.06 \\
\hline & 2 million - less than 3 million & 91 & 25.28 \\
\hline & 3 million - less than 4 million & 79 & 21.94 \\
\hline & 4 million - less than 5 million & 42 & 11.67 \\
\hline & More than 5 million & 47 & 13.06 \\
\hline \multirow{2}{*}{$\begin{array}{l}\text { Residential } \\
\text { Areas }\end{array}$} & Downtown & 323 & 89.72 \\
\hline & Suburban & 37 & 10.28 \\
\hline
\end{tabular}


The mediating variables in this study were presented as 'Do you think the quality of life of local residents is considered in the Jeju tourism development plan?' On whether or not to agree with the final dependent variable 'Over Tourism', the respondents responded with the question 'Do you think that Jeju is currently facing overtourism?'

\subsection{Confirmatory Factor Analysis}

In this study, confirmatory factor analysis (CFA) was performed to apply latent variables in the research model for the PLS-SEM analysis. This process can be seen as a process to verify the validity and reliability of each factor. In addition, considering the number of samples, most studies have 20 times the potential variables and use them as criteria (Sosik, Kahai, \& Piovoso, 2009). The six factors (four exogenous, one mediator, one dependent) and the number of samples applied in this study are 360, so there is no statistical problem. As shown in Table 3, low factor loadings were removed to select the final variables.

Table 3: Confirmatory factor analysis

\begin{tabular}{|c|c|c|c|c|}
\hline Variables & Cultural & Economic & Environmental & Social \\
\hline CL1 & 0.760 & & & \\
\hline CL2 & 0.823 & & & \\
\hline CL3 & 0.825 & & & \\
\hline EC1 & & 0.890 & & \\
\hline EC4 & & 0.633 & & \\
\hline EC5 & & 0.620 & & \\
\hline EN1 & & & 0.852 & \\
\hline EN2 & & & 0.738 & \\
\hline EN3 & & & 0.790 & \\
\hline EN4 & & & 0.844 & \\
\hline EN5 & & & 0.868 & \\
\hline SO1 & & & & 0.777 \\
\hline SO2 & & & & 0.780 \\
\hline SO4 & & & & 0.801 \\
\hline SO5 & & & & 0.761 \\
\hline
\end{tabular}

Note: CL refers to Cultural; EC refers to Economic; EN refers to Environmental; SO refers to Social

\subsection{Hypothesis Testing with PLS-SEM Analysis}

In this study, the partial least squares (PLS) and the structural equation model (SEM) were used to measure the suitability of each proposed model's path and the data collected by the overall model. The combined method PLSSEM was applied. This methodology is largely measured in the PLS for pathways while the suitability of the study model and data in SEM (Hair, Ringle, \& Sarstedt, 2011).

The analysis was conducted with Smartpls 3.0 software (Ringle, Wende, \& Becker, 2015). In order to measure the value of $t$, which is the coefficient value of each path, it was estimated by the bootstrap re-sampling method. Table 5 shows the path value and the value of $\mathrm{R}^{2}$. Each factor in the model shows a positive value and a significant statistical level in the relationship between each path.

The results of this hypothesis testing show that cultural factors affect the quality of life statistically at $1 \%$ significance level, and economic factors are also statistically significant at 5\% significance level. Instead, it can be seen that social and environmental factors are not statistically significant variables in the quality of life of Jeju residents at this time. These four independent factors show low explanatory power $\left(\mathrm{R}^{2}=0.083\right)$, suggesting that other factors are latent. Also, the quality of life variable affects the agreement of overtourism ( $p$-value $1 \%$ significance level). Finally, as a result of considering the demographic variables of residents as one factor, the analysis of overtourism and relevance shows that there is no correlation at this time.

In addition, as shown in Table 6, an indirect effect analysis on whether each independent factor affects the overtourism factor through the parameter of the quality of life of the residents in the research model showed that the cultural factor at 5\% significance level statistically affected, and economic factors were also statistically significant at $10 \%$ significance level. In conclusion, in order to reduce the negative perception of overtourism, it is effective for local residents to implement preferential policies based on cultural and economic factors.

Table 5: Results of PLS-SEM: hypothesis analysis

\begin{tabular}{|c|c|c|c|}
\hline Paths & Coefficient & P-value & $\mathbf{R}^{2}$ \\
\hline Cultural $\rightarrow$ QoL (H1_1) & 0.163 & 0.001 & \multirow{4}{*}{0.083} \\
\hline Economic $\rightarrow$ QoL (H1_2) & 0.144 & 0.020 & \\
\hline Social $\rightarrow$ QoL (H1_3) & 0.055 & 0.215 & \\
\hline Environmental $\rightarrow$ QoL (H1_4) & 0.004 & 0.472 & \\
\hline QoL $\rightarrow$ Overtourism (H2) & 0.152 & 0.001 & \multirow{2}{*}{0.038} \\
\hline Demographic $\rightarrow$ Overtourism (H3) & -0.125 & 0.209 & \\
\hline
\end{tabular}

Note: QoL refers Quality of life 
Table 6: Results of PLS-SEM: indirect effect analysis

\begin{tabular}{|l|c|c|}
\hline \multicolumn{1}{|c|}{ Paths } & Coefficient & P-value \\
\hline Cultural $\rightarrow$ QoL $\rightarrow$ Overtourism & 0.025 & 0.023 \\
\hline Economic $\rightarrow$ QoL $\rightarrow$ Overtourism & 0.022 & 0.055 \\
\hline Social $\rightarrow$ QoL $\rightarrow$ Overtourism & 0.008 & 0.243 \\
\hline Environmental $\rightarrow$ QoL $\rightarrow$ Overtourism & 0.001 & 0.472 \\
\hline
\end{tabular}

Note: QoL refers Quality of life

\section{Conclusion and Implication}

This study focuses on local residents' perception of overtourism, which is emerging as a global issue in Jeju Island, Korea's representative island tourism destination. As a result of the research, the local residents of Jeju Island showed that cultural and economic factors are particularly important among the factors related to overtourism, and they recognize that these factors affect the quality of life when discussing the overtourism issues. It is deeply understandable that Dodds and Butler (2019) noted that, not only residents who are related to tourism business, but also those who are not directly engaged in the business at the tourist destinations may get the same stress which reduces their quality of life as a result of quantitative expansion of the tourism industry, being a foundation of the local economy. Mustafa (2019) emphasized the importance of tourism business due to its multiplier effect especially in the developing countries. Nevertheless, residents of Jeju do not deny the economic effects of tourism in this study case. This result is consistent with Martín et al. (2018) study, which assesses the economic impacts more negatively than the social impacts of the overtourism of local residents. The findings that the control parameters are not significant are also consistent with the results of Muler Gonzalez et al. (2018).

The social and environmental factors that resulted in insignificance among the factors have been criticized as overtourism problems in Jeju Island (Choi et al., 2019). In addition, the environmental seriousness from plastic waste on the coastal area of Jeju beaches is often reported, debating who brought them into the island or who caused the problem (Chang et al., 2020). Yet, the result of this study has not yet touched the issues. Meanwhile, the sentiments of Jeju residents regarding the cultural factors that resulted in the significance of protecting the uniqueness and heritage of Jeju Island as an island tourist destination and providing various cultural opportunities are much valuable. The point that tourism has a fast and long-term ripple effect on the local economy in terms of cross-industry (Faber \& Gaubert, 2019 ) is enough to recognize the best policy of attracting more tourists to stimulate the economy. Moreover, as the prolongation of local economic trends intensifies, it may be obvious that the perception of damage caused by overtourism experienced by local residents becomes the most sensitive barometer in economic terms. The overall tourism business as an economic indicator of the province is critical in terms of quality of life of the residents. It can be interpreted from the result of this study that the authorities of Jeju Island should drew political implications related to cultural and economic factors in order to improve the quality of life of local residents as well as to solve the problems of overtourism.

Jeju Island has its own culture and authenticity as the island's tourist destination, and its natural environment is the main tourist product, so it is necessary to prevent the deterioration of tourist attractions due to overtourism. In addition, as a factor for maintaining sustainability, it is necessary to take measures to prevent conflicts with tourists in advance without degrading the quality of life of local residents due to overtourism. As the conflict between tourists and local residents deepens due to the phenomenon of overtourism, it does not only lower the satisfaction of tourists, but also threatens the quality of life of local residents, which is more likely to develop as anti-tourist activities such as in European cities with serious overtourism. It may bring even more unacceptable consequences in the near future on the island. Therefore, it is necessary to steadily study it in various forms with multiple aspects and conduct longitudinal observation for diverse level (Uysal et al., 2016) from now on as long as Jeju's overtourism research is considered in its infancy.

What is needed for future research is not only to cover the entire subject of Jeju Island, but also to limit the scope to areas where overtourism is particularly severe on Jeju Island. Even in Jeju, especially in areas with notable overtourism indications, the local residents are particularly stressed, which may lead to different results from this study. Jeju Island's overtourism includes disputes like double-faced Janus, increased population density due to the attractiveness of the residential environment and the dilemmas of other tourist cities that result in gentrification. Any complication that originates from social phenomena will be directly linked to environmental issues, resulting in lowering the happiness level of residents as well as inconvenience of tourists. Based on this research, studies on the problems that Jeju Island should solve economically, environmentally, culturally and socially for sustainable tourism that will improve the quality of life of residents on in the future should be pursued. 


\section{References}

Andereck, K. L., \& Nyaupane, G. P. (2011). Exploring the nature of tourism and quality of life perceptions among residents. Journal of Travel research, 50(3), 248-260.

Andereck, K. L., Valentine, K. M., Knopf, R. C., \& Vogt, C. A. (2005). Residents' perceptions of community tourism impacts. Annals of tourism research, 32(4), 1056-1076.

Archer, B., Cooper, C., \& Ruhanen, L. (2005). The positive and negative impacts of tourism. Global tourism, 3, 79-102.

Avond, G., Bacari, C., Limea, I., Seraphin, H., Gowreesunkar, V., \& Mhanna, R. (2019). Overtourism: a result of the Janus-faced character of the tourism industry. Worldwide Hospitality and Tourism Themes, 11(5), 552-565.

Azzopardi, E. (2011). The international competitiveness of Malta as a tourist destination (Doctoral dissertation). Robert Gordon University, Aberdeen, United Kingdom.

Ballester, P. (2018). Barcelona and mass tourism: tourismo-phobia and coexistence. Téoros, Revue de Recherche en Tourisme, $37(2), 9$.

Benner, M. (2019). From overtourism to sustainability: A research agenda for qualitative tourism development in the Adriatic. German Journal of Economic Geography, 1-18. Retrieved January 5, 2020, from https://pdfs.semanticscholar.org/ a445/6ead23e4451860a5d0c154a9c42db8e3ecc8.pdf

Blackall, M. (2019). Global tourism hits record highs - but who goes where on holiday? London, United Kingdom: The Guardian. Retrieved January 12, 2020, from https://www.theguar dian. com/news/2019/jul/01/global-tourism-hits-record-h ighs-butwho-goes-where-on-holiday

Brougham, J. E., \& Butler, R. W. (1981). A segmentation analysis of resident attitudes to the social impact of tourism. Annals of tourism research, 8(4), 569-590.

Butler, R. W. (1980). The concept of a tourist area cycle of evolution: implications for management of resources. The Canadian Association of Geographers, 24(1), 5-12.

Butler, R. W. (1999). Sustainable tourism: A state-of-the-art review. Tourism geographies, 1(1), 7-25.

Capocchi, A., Vallone, C., Pierotti, M., \& Amaduzzi, A. (2019). Overtourism: A Literature Review to Assess Implications and Future Perspectives. Sustainability, 11(12), 3303.

Chang, M., Heo, Y., \& Lim H. (2019). 'Moving to Jeju': An Exploratory Keyword Analysis Using Social Big Data. Journal of Tourism \& Industry Research, 39(1), 15-26.

Chang, M., Xing, Y. Y., Zhang, Q. Y., Han, S. J., \& Kim, M. (2020). A CNN Image Classification Analysis for 'CleanCoast Detector' as Tourism Service Distribution. Journal of Distribution Science, 18(1), 15-26.

Cheung, K. S., \& Li, L. H. (2019). Understanding visitor-resident relations in overtourism: developing resilience for sustainable tourism. Journal of Sustainable Tourism, 27(8), 11971216.
Choi, K. W., Kim, M., Chang, M., \& Koo, B. J. (2019). Evaluation on Overtourism in Jeju Island. Journal of Tourism \& Industry Research, 39(2), 29-36.

Coccossis, H., \& Mexa, A. (2017). The challenge of tourism carrying capacity assessment: Theory and practice ( $\left.1^{\text {st }} \mathrm{ed}.\right)$. London, United Kingdom: Routledge.

Diedrich, A., \& García-Buades, E. (2009). Local perceptions of tourism as indicators of destination decline. Tourism Management, 30(4), 512-521.

Dodds, R., \& Butler, R. W. (2019). The enablers of overtourism. In R. Dodds \& R. W. Butler (Eds.), Overtourism: Issues, Realities and Solutions (pp.6-26). Berlin, Germany: Walter de Gruyter $\mathrm{GmbH}$.

Doxey, G. V. (1975, September). A causation theory of visitorresident irritants: Methodology and research inferences. In Sixth Annual Conference Proceedings, 'The Impact of Tourism' (pp. 8-11). Lapeer, MI: Travel and Tourism Research Association.

Erschbamer, G., Innerhofer, E., \& Pechlaner, H. (2018). Overtourism: How Much Tourism is Too Much. Bolzano, Italy: Eurac Research.

Faber, B., \& Gaubert, C. (2019). Tourism and economic development: evidence from Mexico's coastline. American Economic Review, 109(6), 2245-93.

Faulkner, B., \& Tideswell, C. (1997). A framework for monitoring community impacts of tourism. Journal of sustainable tourism, 5(1), 3-28.

Goodwin, H. (2019). Overtourism. Causes, Symptoms and Treatment. Tourismus Wissen-quarterly, 110-114. Retrieved January 3, 2020, from https://responsibletourismpartner ship. org/wp-content/uploads/2019/06/TWG16-Goodwin. pdf

Gutiérrez-Taño, D., Garau-Vadell, J. B., \& Díaz-Armas, R. J. (2019). The influence of knowledge on residents' perceptions of the impacts of overtourism in $\mathrm{P} 2 \mathrm{P}$ accommodation rental. Sustainability, 11(4), 1043.

Guttentag, D. (2015). Airbnb: disruptive innovation and the rise of an informal tourism accommodation sector. Current issues in Tourism, 18(12), 1192-1217.

Hair, J. F., Ringle, C. M., \& Sarstedt, M. (2011). PLS-SEM: Indeed a silver bullet. Journal of Marketing theory and Practice, 19(2), 139-152.

Hall, C. M., \& Rath, J. (2007). Tourism, migration and place advantage in the global cultural economy. In Tourism, ethnic diversity and the city (pp. 19-42). New York, NY: Routledge.

Hall, C. M. (2012). Island, islandness, vulnerability and resilience. Tourism Recreation Research, 37(2), 177-181.

Jeju Weekly (2020). Jeju Recovers 15 Million Tourists in 2019. Jeju, Korea: The Jeju Weekly. Retrieved January 13, 2020, from http://www.jejuweekly.com/news/article View. html?idxno $=6123$

Jordan, E. J., Lesar, L., \& Spencer, D. M. (2019). Clarifying the Interrelations of Residents' Perceived Tourism-Related Stress, Stressors, and Impacts. Journal of Travel Research, 1, 12. 
Joshi, S., \& Dahal, R. (2019). Relationship between Social Carrying Capacity and Tourism Carrying Capacity: A Case of Annapurna Conservation Area, Nepal. Journal of Tourism and Hospitality Education, 9, 9-29.

Jung, M. H. (2020). The Effect of Social Capital on Personal Happiness: A Focus on Service Industry Employees. The Journal of Asian Finance, Economics and Business (JAFEB), 7(1), 291-299.

Kim, K., Uysal, M., \& Sirgy, M. J. (2013). How does tourism in a community impact the quality of life of community residents? Tourism management, 36, 527-540.

Kim, M. S., Thapa, B., \& Kim, H. (2018). International Tourists' Perceived Sustainability of Jeju Island, South Korea. Sustainability, 10(1), 73.

Kim, D. H. (2018). The effects of city brand image on city brand recognition and city loyalty. International Journal of Industrial Distribution \& Business, 9(3), 69-79.

Koens, K., Postma, A., \& Papp, B. (2018). Is overtourism overused? Understanding the impact of tourism in a city context. Sustainability, 10(12), 4384.

Kuščer, K., \& Mihalič, T. (2019). Residents' Attitudes towards Overtourism from the Perspective of Tourism Impacts and Cooperation-The Case of Ljubljana. Sustainability, 11(6), 1823.

Lawton, T. C. (2017). Cleared for take-off: Structure and strategy in the low fare airline business. New York, NY: Routledge.

Liu, J. C., Sheldon, P. J., \& Var, T. (1987). Resident perception of the environmental impacts of tourism. Annals of Tourism research, 14(1), 17-37.

Martín, J., Guaita Martínez, J., \& Salinas Fernández, J. (2018). An analysis of the factors behind the citizen's attitude of rejection towards tourism in a context of overtourism and economic dependence on this activity. Sustainability, 10(8), 2851.

Muler Gonzalez, V., Coromina, L., \& Gali, N. (2018). Overtourism: residents' perceptions of tourism impact as an indicator of resident social carrying capacity-case study of a Spanish heritage town. Tourism Review, 73(3), 277-296.

Mustafa, A. M. M. (2019). Contribution of Tourism and Foreign Direct Investment to Gross Domestic Product: Econometric Analysis in the Case of Sri Lanka. Journal of Asian Finance, Economics and Business, 6(4), 109-114. https://doi. org/10.13106/jafeb.2019.vol6.no4.109

Oklevik, O., Gössling, S., Hall, C. M., Steen Jacobsen, J. K., Grøtte, I. P., \& McCabe, S. (2019). Overtourism, optimisation, and destination performance indicators: A case study of activities in Fjord Norway. Journal of Sustainable Tourism, 27(12), 18041824.

Perkumienè, D., \& Pranskūnienè, R. (2019). Overtourism: Between the Right to Travel and Residents' Rights. Sustainability, 11(7), 2138.

Pham, K., Andereck, K., \& Vogt, C. (2019). Local residents' perceptions about tourism development. Proceedings of Travel and Tourism Research Association International Conference, (74). Melbourne, Australia: TTRA.

Ratz, T. (2003). 3 Residents' pereeptions of the socio-cultural impacts of tourism at Lake Balaton, Hungary. Tourism and Sustainable Community Development, 7, 36.

Ringle, C. M., Sarstedt, M., \& Straub, D. W. (2012). A critical look at the use of PLS-SEM in MIS quarterly. Management Information System Quarterly, 36.

Ringle, C. M., Wende, S., \& Becker, J. M. (2015). SmartPLS 3. SmartPLS GmbH, Boenningstedt. Journal of Service Science and Management, 10(3). May 22, 2020, from https:// www. scirp.org/(S(vtj3fa45qm1 ean45vvffcz55))/reference/ ReferencesPapers.aspx?ReferenceID $=2060940$

Saarinen, J. (2006). Traditions of sustainability in tourism studies. Annals of tourism research, 33(4), 1121-1140.

Seraphin, H., Sheeran, P., \& Pilato, M. (2018). Over-tourism and the fall of Venice as a destination. Journal of Destination Marketing \& Management, 9, 374-376.

Shafaei, F., \& Mohamed, B. (2015). A Stage-Based Model Development Study on Tourism Social Impact Assessment. International Journal of Scientific and Research Publication, 3(5), 279-284.

Sosik, J. J., Kahai, S. S., \& Piovoso, M. J. (2009). Silver bullet or voodoo statistics? A primer for using the partial least squares data analytic technique in group and organization research. Group \& Organization Management, 34(1), 5-36.

Szromek, A. R., Kruczek, Z., \& Walas, B. (2020). The Attitude of Tourist Destination Residents towards the Effects of Overtourism-Kraków Case Study. Sustainability, 12(1), 228.

Tulsi, P., \& Ji, Y. H.. (2020). A Conceptual Approach to Green Human Resource Management and Corporate Environmental Responsibility in the Hospitality Industry. Journal of Asian Finance, Economics and Business, 7(1), 195-203. https://doi. org/10.13106/jafeb.2020.vol7.no1.195

UNWTO. (2018). 'Over tourism'? Understanding and Managing Urban Tourism Growth beyond Perceptions. Retrieved from https://www.e-unwto.org/doi/pdf/10.18 111/ 9789284420070

UNWTO. (2019, November). Solid growth in international arrivals in January-September 2019, though uneven across regions. World Tourism Barometer and Statistical Annex, 17(4). Retrieved from https://www.e-unwto.org/doi/pdf/10.18111/ wtobarometereng.2019.17.1.4

Uysal, M., Sirgy, M. J., Woo, E., \& Kim, H. L. (2016). Quality of life (QOL) and well-being research in tourism. Tourism Management, 53, 244-261.

Vogel, H. L. (2016). Travel industry economics: a guide for financial analysis (3rd ed.). New York, NY: Springer.

Zhang, J., Inbakaran, R. J., \& Jackson, M. S. (2006). Understanding community attitudes towards tourism and host-Guest interaction in the urban-rural border region. Tourism Geographies, 8(2), 182-204. 